\title{
Death-rate row blurs mutant flu debate
}

\author{
Even if a $59 \%$ mortality rate for H5N1 is too high, the virus \\ could still cause a flu pandemic more serious than that of 1918.
}

\section{BY DECLAN BUTLER}

$\mathrm{W}$ hen the US National Science Advisory Board for Biosecurity called for redaction of two papers on mutant strains of $\mathrm{H} 5 \mathrm{~N} 1$ avian influenza virus, one reason it cited was the high fatality rate of the wild virus ${ }^{1}$. But some virologists claim that the mortality rate $-59 \%$ in officially confirmed cases (see go.nature. com/3ys4py) - has been vastly overestimated.

In an opinion article ${ }^{2}$ published last month, Peter Palese and Taia Wang, virologists at Mount Sinai School of Medicine in New York, argued that the $59 \%$ figure

우 was "driving this

controversy", but

that it was "likely

orders of magnitude too high". Vincent Racaniello, a virologist at Columbia University in New York, told Nature that he believes any $\mathrm{H} 5 \mathrm{~N} 1$ pandemic would not come close to the $2-2.5 \%$ global mortality rate of the 1918 flu pandemic.

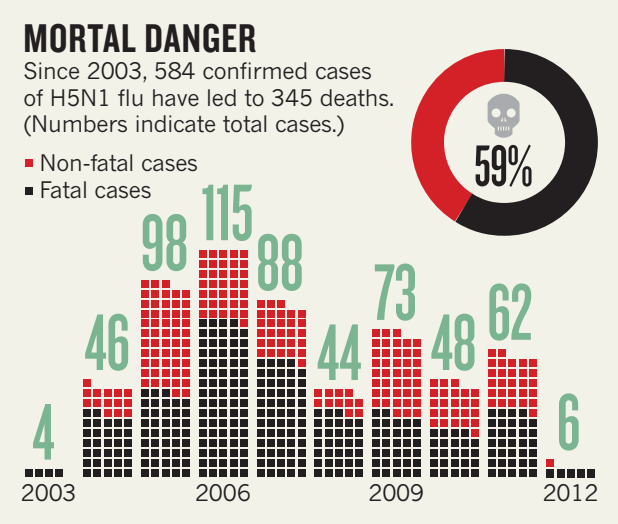

All of the others found much lower levels, and most found no detectable antibody.

"The consensus is that the rates are quite low, though not non-existent," says Peiris.

Jeremy Farrar, director of the Oxford University Clinical Research Unit in Ho Chi Minh City, Vietnam, agrees. "Across southeast Asia we have not found much evidence of seropositivity," he says. A review of H5N1 seroprevalence studies published last year ${ }^{5}$ also concluded that "transmission of the H5N1 virus from poultry to humans is rare".

Racaniello says that the studies that found no or little seroprevalence "were simply done in the wrong populations", and that more studies are needed.

Many scientists say that focusing on the exact numbers misses the wider picture - even if the fatality rate has been overestimated, the virus is still a severe pandemic threat. "I don't care whether this virus has a case-fatality rate of $50 \%$ or $5 \%$ or $1 \%$, it would still be

The virologists are reviving an old argument ${ }^{3}$ that the $59 \%$ rate, derived from officially confirmed World Health Organization (WHO) numbers of cases and deaths (see 'Mortal danger'), does not take into account undetected cases or asymptomatic infections.

Since the current H5N1 outbreak began in 2003, researchers have done several seroprevalence surveys looking for antibodies to the virus in people from outbreak areas. Racaniello and his colleagues say that some survey results imply that $\mathrm{H} 5 \mathrm{~N} 1$ infections are common and the fatality rate is low. But all other scientists contacted by Nature disagree.

Malik Peiris, a flu virologist at the University of Hong Kong, says that the higher seroprevalence rates seem to be outliers. One study found that $5.6 \%$ of people tested had antibodies against H5N1 (ref. 4).

\section{DNATURE.COM} For more on mutant H5N1 flu: nature.com/mutantflu a really big problem," says Marc Lipsitch, an epidemiologist at the Harvard School of Public Health in Boston, Massachusetts.

In fact, although the true mortality rate of H5N1 is likely to be lower than $59 \%$, the epidemiological data suggest that it would dwarf the $0.1-0.4 \%$ rate assumed in many countries' pandemic preparedness plans, and could far exceed that of the 1918 pandemic. Robert Webster, a flu virologist at St Jude Children's Research Hospital in Memphis, Tennessee, warns that the $\mathrm{H} 5 \mathrm{~N} 1$ virus is a fearsome pathogen. "You walk into a poultry house that has this virus and everything is dead," he says. "If that sort of virus were to get into humans ... my God." -

1. Berns, K. I. et al. Nature 482, 153-154 (2012).

2. Palese, P. \& Wang, T. Proc. Natl Acad. Sci. USA http:// dx.doi.org/10.1073/pnas.1121297109 (2012).

3. Butler, D. Nature 439, 124-125 (2006).

4. Khuntirat, B. P. Clin. Infect. Dis. 53, e107-e116 (2011).

5. Van Kerkhove, M. D. etal. PLOS ONE 6, e14582 (2011). 